\title{
A new flesh fly species of Oxysarcodexia Townsend from the Brazilian Atlantic Forest and redescription of Oxysarcodexia xon (Dodge, 1968)
}

\author{
Marco Antônio Menezes ${ }^{1,2}$; Josenilson Rodrigues dos Santos ${ }^{1,3}$ \& Cátia Antunes de Mello Patiu ${ }^{1,4}$ \\ 1 Universidade Federal do Rio de Janeiro (UFRJ), Museu Nacional (MN), Departamento de Entomologia, Laboratório de Diptera Neotropicais. \\ Rio de Janeiro, RJ, Brasil. \\ 2 Programa de Pós-Graduação em Ciências Biológicas (Zoologia). ORCID: http://orcid.org/0000-0002-4056-0286. E-mail: menezes.marcof@gmail.com \\ 3 Programa de Pós-Graduação em Ciências Biológicas (Zoologia). ORCID: http://orcid.org/0000-0002-5491-8541. E-mail: jrsantos@mn.ufrj.br \\ ${ }^{4}$ ORCID: http://orcid.org/0000-0002-0162-0952. E-mail: camello@acd.ufrj.br
}

\begin{abstract}
A new Neotropical species of Oxysarcodexia Townsend (Diptera, Sarcophagidae) from Atlantic Forest of southeastern Brazil, Oxysarcodexia digitata sp. nov., is described and illustrated based on male and female specimens. This new species resembles 0. fraterna Lopes, 0. nitida Soares \& Mello-Patiu, 0. notata Soares \& Mello-Patiu, 0. vittata (Walker), and 0. xon (Dodge), but can be distinguished based on differences in phallic elements. Additionally, the male of Oxysarcodexia xon (Dodge, 1968) is redescribed and illustrated, its female is described for the first time, and new records is presented.
\end{abstract}

Key-Words. Sarcophagidae; Neotropical; Taxonomy; Morphology.

\section{INTRODUCTION}

Oxysarcodexia Townsend, 1917 has 90 known species and it is one of the largest genera of Sarcophagidae, with 83 species recorded in the Neotropical region (Lopes \& Tibana, 1987; Pape, 1996; Soares \& Mello-Patiu, 2010; Souza \& Paseto, 2015; Souza \& Buenaventura, 2016; Carvalho-Filho et al., 2017; Dufek \& Mulieri, 2017). The genus diversity associated with the great similarity among the species lead to a difficulty in the identification at species level (Pape \& Dahlem, 2010; Soares \& MelloPatiu, 2010). Adults of Oxysarcodexia are one of the most frequent and abundant flesh flies reported in field collections, including studies on decomposition process using carrion-baited traps or pigs, and also in human corpses (Carvalho et al., 2000; Martínez et al., 2007; Barros et al., 2008; Barbosa et al., 2009; Battán Horenstein et al., 2010; OliveiraCosta et al., 2001, 2014; Oliveira \&Vasconcelos, 2010; Lindgren et al., 2015; de Faria et al., 2017). The results of these experiments have highlighted a probable forensic importance of this genus in the Neotropics (Alves et al., 2014; Sousa et al., 2015; Barbosa et al., 2017). Moreover, their larvae have been mainly reported as decomposers of organic material, more specifically as dung and carrion-breeders (Mendes \& Linhares, 2002; Carvalho et al., 2012).
Oxysarcodexia has been considered as a monophyletic group, supported mainly by presence of a "tooth-like" or lateral triangular extension of the phallic tube above the vesica (Lopes, 1946; Dodge, 1966; Giroux et al., 2010; Dufek \& Mulieri, 2017; Buenaventura \& Pape, 2017) and juxta with a proximal convex membranous expansion (Buenaventura \& Pape, 2017). Moreover, the genus species can be recognized for also having postalar wall setose, tegula dark and basicosta yellowish, male mid femur with a ctenidium of flattened spine-like setae, male sternite 5 with a deep cleft with almost parallel edges (few exceptions), phallus with basi- and distiphallus connected with a desclerotized strip between them, acrophallus with three short conducting styli, vesica enlarged with very ornamented distal section, and juxta connected to the paraphallus, wrinkled proximally and smooth distally (Lopes, 1946; Dodge, 1966; Pape, 1996; Carvalho \& Mello-Patiu, 2008; Silva \& Mello-Patiu, 2008; Dufek \& Mulieri, 2017; Buenaventura \& Pape, 2017).

Males of some Oxysarcodexia species have a characteristic distal enlargement of the phallus and have been referred as "xon species-group" or "Xarcophaga group", considered as a distal enlargement of the juxta by Souza \& Paseto (2015), but often this enlargement involves both the juxta 
and the apical portion of the paraphallus. Dodge (1968) proposed the monotypic genus Xarcophaga to include a new species, $X$. xon, described only by males. The author sustained this genus separated from Oxysarcodexia, especially by the elongated and slender phallus, with a characteristic apical enlargement. Lopes (1975a) synonymized this monotypic genus with Oxysarcodexia. Later on, Lopes (1982) considered Xarcophaga and Oxysarcodexia as valid and distinct genera and also included Xarcophaga, Oxysarcodexia, Apelophyla Hall and Hybopygia Enderlein into the subtribe Oxysarcodexiina (tribe Raviniini), without any clear argument. Pape (1996) synonymized all these four genera under Oxysarcodexia. Subsequent authors have agreed with this genus concept and other species of Oxysarcodexia referred under "xon species-group" or "Xarcophaga group" have been described (Soares \& Mello-Patiu, 2010; Souza \& Paseto, 2015; Souza \& Buenaventura, 2016; Dufek \& Mulieri, 2017). Currently, there are 13 species of Oxysarcodexia recognized by several authors as related to "xon species-group": O. berthet Dufek \& Mulieri, 2017; O. catica Souza \& Buenaventura, 2016; O. favorabilis (Lopes, 1935); O. fraterna Lopes, 1946; O. ibera Dufek \& Mulieri, 2017; O. liliarum Souza \& Buenaventura, 2016; O. mineirensis Souza \& Paseto, 2015; O. nitida Soares \& Mello-Patiu, 2010; O. notata Soares \& Mello-Patiu, 2010; O. pallisteri Dodge, 1966; O. peruviana (Lopes, 1975b); O. vittata (Walker, 1836) and O. xon (Dodge, 1968).

Herein, we describe a new species of Oxysarcodexia from the Atlantic Forest of southeastern Brazil related to "xon species-group". As the original description of O. xon is incomplete in relation to the phallic morphology, the male of $O$. xon is also redescribed and illustrations are provided to enable its safe differentiation from congeneric species. The female of $O$. xon is described for the first time.

\section{MATERIAL AND METHODS}

The studied material comprised males and females, 13 specimens of Oxysarcodexia digitata sp. nov. and ten specimens of $O$. xon, housed in the Entomological Collection of the Museu Nacional, Universidade Federal do Rio de Janeiro, Rio de Janeiro, Brazil (MNRJ). Unfortunately, part of examined material cited herein, including five paratypes of the new species and nine specimens of O.xon, was lost in the fire of September $2^{\text {nd }}$, 2018 at the MNRJ, and it is indicated as [lost] in the list (Duarte, 2019). However, the holotype and seven paratypes of $O$. digitata sp. nov. and one specimen of $O$. xon from Itatiaia, state of Rio de Janeiro, were identified after the tragic fire among material obtained by donation to compose the new Entomological Collection of MNRJ. The holotype of $O$. xon, housed in the Entomological Collection of University of Kansas Biodiversity Institute, Lawrence, Kansas (KU), was examined through high-resolution photographs.

We used the terminology of Cumming \& Wood (2017) for external morphology with abbreviations T and ST for abdominal tergites and sternites. Terminology of phallic morphology follows Mello-Patiu \& Pape (2000), except the terms "median stylus", "paraphallus" and "anterior juxtal margin", which follow the concept of Giroux et al. (2010), Whitmore et al. (2013) and Souza \& Buenaventura (2016), respectively, and the terminology of female terminalia follows Mello-Patiu \& Santos (2001). Label of holotype of Oxysarcodexia digitata sp. nov. are cited verbatim, lines separated by a slash, different labels by a double slash, comments or corrections in square brackets. New records of Oxysarcodexia xon are indicated with an asterisk in geographic distribution.

Terminalia were dissected, cleared in a hot $10 \% \mathrm{KOH}$ solution, and neutralized in an acetic acid-ethanol solution. They were temporarily mounted in glycerin on glass slides, observed, and illustrated using a MOTIC K400 ${ }^{\circledR}$ stereomicroscope and a ZEISS $M 80^{\circledR}$ microscope, both with camera lucida. After study, the dissected terminalia were placed in microvials filled with glycerin and pinned with their respective specimens. Photographs were taken with a Leica DFC450C digital camera mounted on a Leica M205 stereomicroscope and final composite images were digitally stacked by the software Leica Application Suite version 4.8.0. Images were edited using Adobe Photoshop $\mathrm{CS}^{\circledR}$ and Adobe Illustrator $\mathrm{CS}^{\circledR}$ (Adobe Systems, Inc., San Jose, CA).

\section{RESULTS}

\section{Taxonomy}

\section{Oxysarcodexia digitata sp. nov. (Figs. 1A-D, 2A-C, 3A-F)}

Type-material: Holotype ơ (MNRJ): "Brasil, RJ, Itatiaia, P.N. [Parque Nacional] Itatiaia / Trilha [trail] Rui Braga,

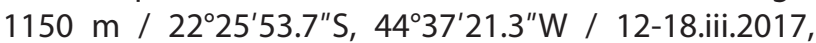
Van Someren 2 / peixe [fish], Nihei et al. col. [printed on white paper] // HOLOTYPE [printed on white paper, surrounded by a red line] // Oxysarcodexia digitata n. sp. / Menezes, Santos \& Mello-Patiu / 2020 / Det.: Menezes, Santos \& Mello- / Patiu 2019 // MNRJ-ENT1-57099 [QR code, printed on white paper]". Condition of holotype: good condition, terminalia not dissected. Paratypes (MNRJ): Brazil: 1 ơ, 3 o: São Paulo, Boracéia, 20.iii.1968, breeding 800, H.S. Lopes col. [lost]; 1 ơ: Rio de Janeiro, Itatiaia, 19-21.vi.1955, Dalcy, Barros \& Pearson col. [lost]; $10^{7}$ same data as holotype, except $1149 \mathrm{~m}, 22^{\circ} 25^{\prime} 59.7^{\prime \prime} \mathrm{S} /$

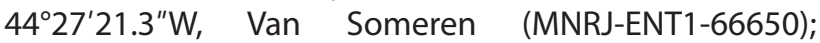
2 ơ: same data as holotype (MNRJ-ENT1-57100 and (MNRJ-ENT1-57101)); 4 o': same data as holotype, except 1198 m, 22²6'09.1"S/ 44³7'31.2"W, 12-18.iii.2017, Van Someren, shrimp (MNRJ-ENT1-57102, MNRJ-ENT1-57103, MNRJ-ENT1-57104, MNRJ-ENT1-57105). Conditions of preserved paratypes: good conditions, one of them without mid right leg (MNRJ-ENT1-57100), another one without hind left leg, with hind right leg and left wing glued on card (MNRJ-ENT1-57102) and another one without all right legs (MNRJ-ENT1-66650). 
Diagnosis: Male pregonite with flat triangular projection in the ventral margin (Fig. 1D), postgonite with a short median seta (Fig. 1D) and anterior juxtal margin as peculiar folded digitate lobes (Figs. 1C-D, 3C, 3E), and vesica with four extensions, $\mathrm{X}$-shaped, in ventral view (Fig. 1C). Female T6 divided in two sclerotized plate (Figs. 2A-B), T8 absent, ST8 short, with a rounded, setose, and poorly delimited apical area (Fig. 2A), and vaginal plate membranous and poorly delimited (Fig. 2B).

Description: Male $(n=10)$. Length: $10-12 \mathrm{~mm}$.

Head: Parafacial, fronto-orbital plate and posterior ocular orbits dark brown with intense golden pruinosity (Figs. 3A-B); parafacial with a row of setulae close to the eye; face with golden slightly silvery pruinosity; facial ridge dark brown with short setulae in the inferior half; frons about $0.23-0.24 x$ head width at level of ocellar triangle; frontal vitta brownish; 9-11 well-developed frontal setae reaching the apex of pedicel; reclinate orbital seta present and more developed than the largest frontals, proclinate orbitals setae absent; ocellar setae as developed as the upper frontals; postocellar setae and paravertical setae of same size of the ocellar setae; inner vertical seta $3 \mathrm{X}$ the outer one; gena with golden pruinosity and black setae; postgena gray slightly silvery pruinose with a few black setae anteriorly and pale setae in the rest; post-cranium with two rows of black occipital setae on upper part and pale setae below; antenna dark brown (Fig. 3A), first flagellomere with silvery pruinosity and approximately $2.5 x$ longer than pedicel; arista long plumose on basal 3/4; palpus dark brown (Fig. 3A). Thorax: Dark brown with silvery gray pruinosity, but golden in the lateral stripes (Figs. $3 A-B)$. Chaetotaxy: acrostichals $0+2$, dorsocentrals $3+3$ (well developed), intra-alars $3+2$, supra-alars $2+3$, postpronotals 3 , notopleurals 4; postalar wall setulose; postalar callus with 2 setae; scutellum with 3 marginal setae (well developed), a pair of discal and a pair of weak apical setae; katepisternal setae 3, almost in a straight line; meral setae 8-9; proepisternum bare; prosternum setulose. Wing: hyaline with dark brown veins (Figs. 3A-B), tegula blackish, whitish-yellow basicosta, vein $R_{4+5}$ with dorsal setulae on $3 / 4$ of distance to crossvein $r-m$, vein $R_{1}$ bare, cell $r_{4+5}$ open at wing margin, costal spine not differentiated, third costal sector ventrally bare, upper and lower calypter whitish. Legs: dark brown with pulvilli yellowish-brown (Fig. 3A); fore femur with rows of dorsal, posterodorsal and posteroventral setae; fore tibia with 3 anterodorsal setae in basal third and 1 posterior setae in the apical third; mid femur with rows of anterior and anteroventral setae, and a row of setae and a ctenidium of flattened spines in posteroventral margin, 2 preapical posterodorsal setae; mid tibia with 1 median anterior, 1 median posterior and 1 median posterodorsal seta; hind trochanter with normal median-ventral setae; hind femur with rows of anteroventral and anterodorsal setae, 1 preapical posterior and 2 preapical posterodorsal setae; hind tibia with 1 basal third, 1 median and 1 preapical seta in anterodorsal and posterodorsal margins and 1 median anteroventral setae.
Abdomen: Dark brown with silver stains (Figs. 3A-B). T4 with one pair of median marginal setae and 2-3 of lateral marginal setae, T5 with about 14 strong marginal setae; ST2-4 subsquadrate; ST5 yellowish brown with a median deep cleft. Terminalia: Syntergosternite 7+8 and epandrium yellowish-brown with dorsal golden pruinosity (Fig. 3C). Syntergosternite $7+8$ with 4 pairs of well-developed setae in posterior margin; epandrium with setae more developed in dorsal margin. Cercus with numerous long setae in cercal base, cercal prong widely covered of pale microtrichia, with short and sparse setae, apex slightly curved outside (Figs. 1A-B, 3C-D); surstylus pyriform, with setae in apical third (Figs. 1A, 3C); postgonite almost straight with slightly spatulate and curved apical end and a short median seta (Fig. 1D); pregonite slightly curved, larger and wider than postgonite, with a blackish apex and a flat triangular projection in the ventral margin (Fig. 1D); phallus well sclerotized, elongated and apically enlarged, basiphallus and distiphallus fused, with a ventral desclerotized band (Fig. 1D); lateral triangular extension of the paraphallus poorly extended (Figs. 1D, 3C); apical portion of paraphallus and juxta folded backwards, juxta yellowish and partially membranous, anterior juxtal margin forming lobes with conspicuously digitate edges (Figs. 1C-D, 3C, 3E); vesica $X$-shaped in ventral view, composed by two portions in lateral view, distal portion sub-triangular and less sclerotized and proximal one slender and curved (Figs. 1C-D, 3C); median and lateral styli apically displaced and very short (Fig. 1C).

Female $(n=3)$ : Length: $8-9 \mathrm{~mm}$. Differs from male as follows:

Head: Frons about 0.18-0.20x head width at level of ocellar triangle; 2 proclinate orbital setae similar to or slightly shorter than the reclinate orbitals; outer vertical seta slightly shorter than the inner one. Thorax: Mid femur without ctenidium. Abdomen: T5 with numerous marginal setae; posterior margin ventrally closed (Fig. 3F). Terminalia: T6 divided as two plates dorsally broad and membranous on midline, posterior margin with a row of stronger marginal setae (Figs. 2A-B); spiracle 6 in the intersegmental membrane and spiracle 7 in tergal plate (Figs. 2A-B); T7 and T8 absent; ST6-8 fused (Figs. 2A-B); ST6 with numerous marginal setae (Figs. 2A-B); ST7 about $2 \mathrm{X}$ the ST6 length, with numerous setae in the posterior margin (Figs. 2A-B); ST7-ST8 fused, without a clear delimitation, ST8 short, with a rounded and setose apical area (Figs. 2A-B); epiproct membranous with one pair of setae; hypoproct broad with long setae (Figs. 2A-B); cercus broad and rounded (Figs. 2A-B); vaginal plate membranous and poorly delimited (Figs. 2A-B); spermathecae oval and striated (Fig. 2C).

Distribution: Brazil (Rio de Janeiro, São Paulo).

Etymology: The species epithet is derived from the Latin digitata (adjective, feminine), meaning fingers, in allusion to the ornamentation of anterior juxtal margin in the phallus, which forms a digitate lobe. 


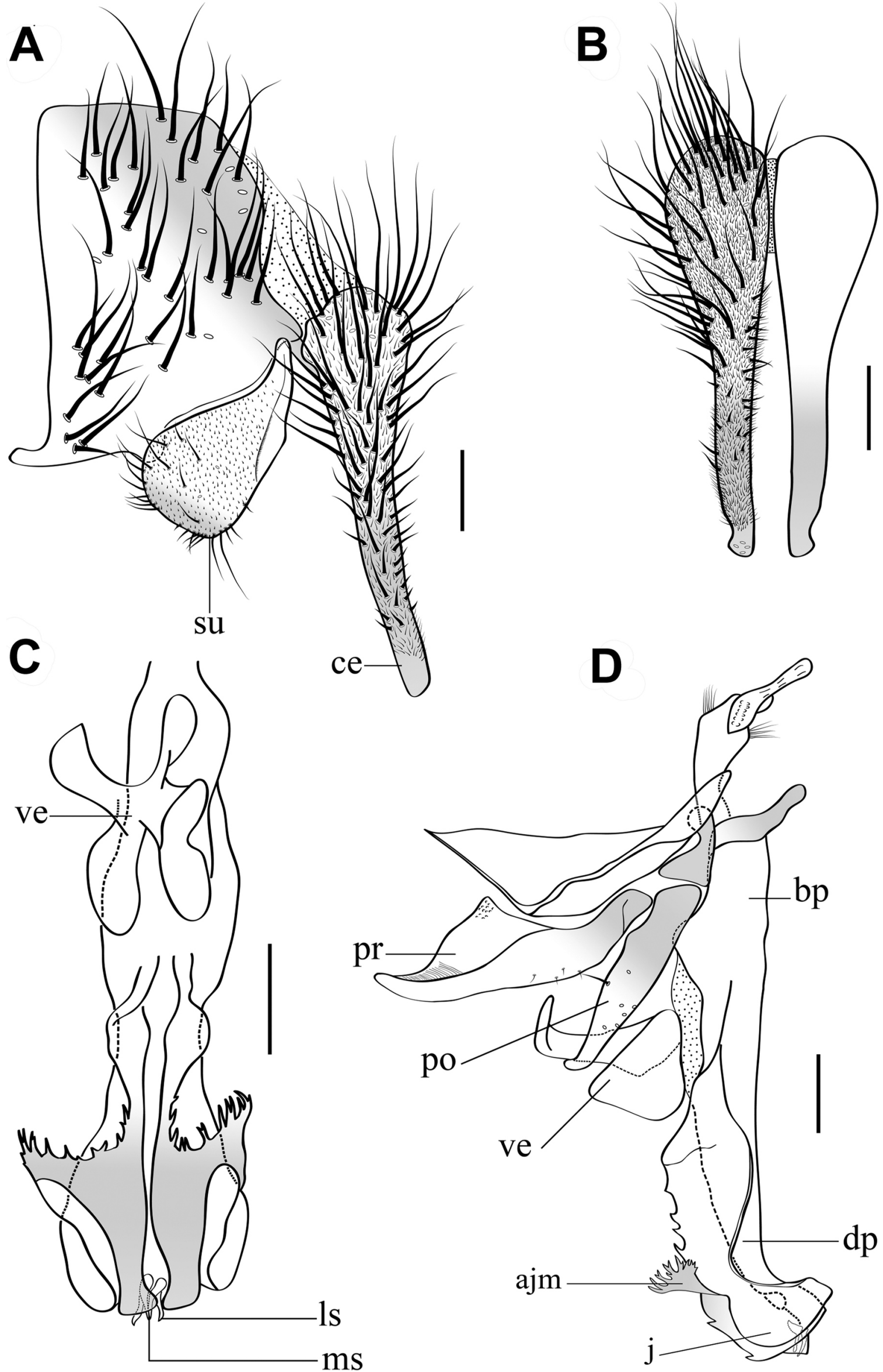

Figure 1. Oxysarcodexia digitata sp. nov. (male paratype from Itatiaia, MNRJ). (A) Epandrium, cercus and surstylus, lateral view. (B) Cercus, posterior view. (C) Phallus, ventral view. (D) Phallus and associated structures, lateral view. Abbreviations: ajm, anterior juxtal margin; $b p$, basiphallus; $c e$, cercus; $d p$, distiphallus; $j$, juxta; $I s$, lateral stylus; $m s$, median stylus; $p o$, postgonite; pr, pregonite; su, surstylus; ve, vesica. Scale bars $=0.2 \mathrm{~mm}$. 
Remarks: Oxysarcodexia digitata sp. nov. is morphologically similar to O. fraterna Lopes, O. nitida Soares \& MelloPatiu, O. notata Soares \& Mello-Patiu, O. vittata (Walker), and $O$. xon. The male terminalia of these species have postgonite with a short median seta, unlike most species of Oxysarcodexia that show long median seta, and the anterior juxtal margin with serrate or digitate edge, not straight. It differs from other species by the peculiar pregonite with a flat triangular projection in the ventral margin (Fig. 3D), the anterior juxtal margin with an edge conspicuously digitate (Figs. 1C-D, 3C, 3E) and the vesica $X$-shaped in ventral view (Figs. 1C-D, 4C).

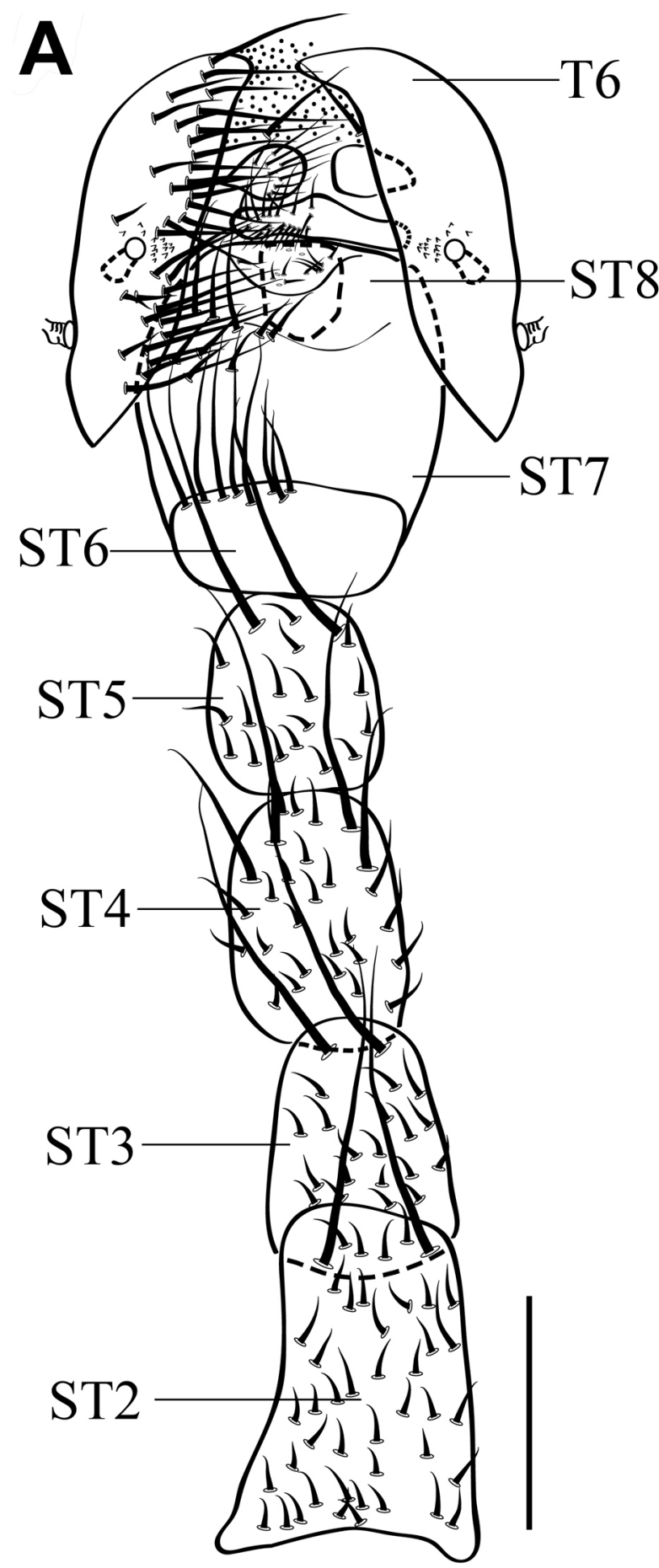

\section{Oxysarcodexia xon (Dodge, 1968)}

(Figs. 4A-D, 5A-F)

Xarcophaga xon Dodge, 1968: 449. Type locality: Panama, Barro Colorado Island.

Oxysarcodexia xon; Lopes, 1975a; Pape, 1996.

Xarcophaga xon; Lopes, 1982.

References: Lopes (1975a, moved to Oxysarcodexia Townsend); Lopes (1982, revalidation of the genus); Pape (1996, catalog); Mello-Patiu et al. (2009, checklist).
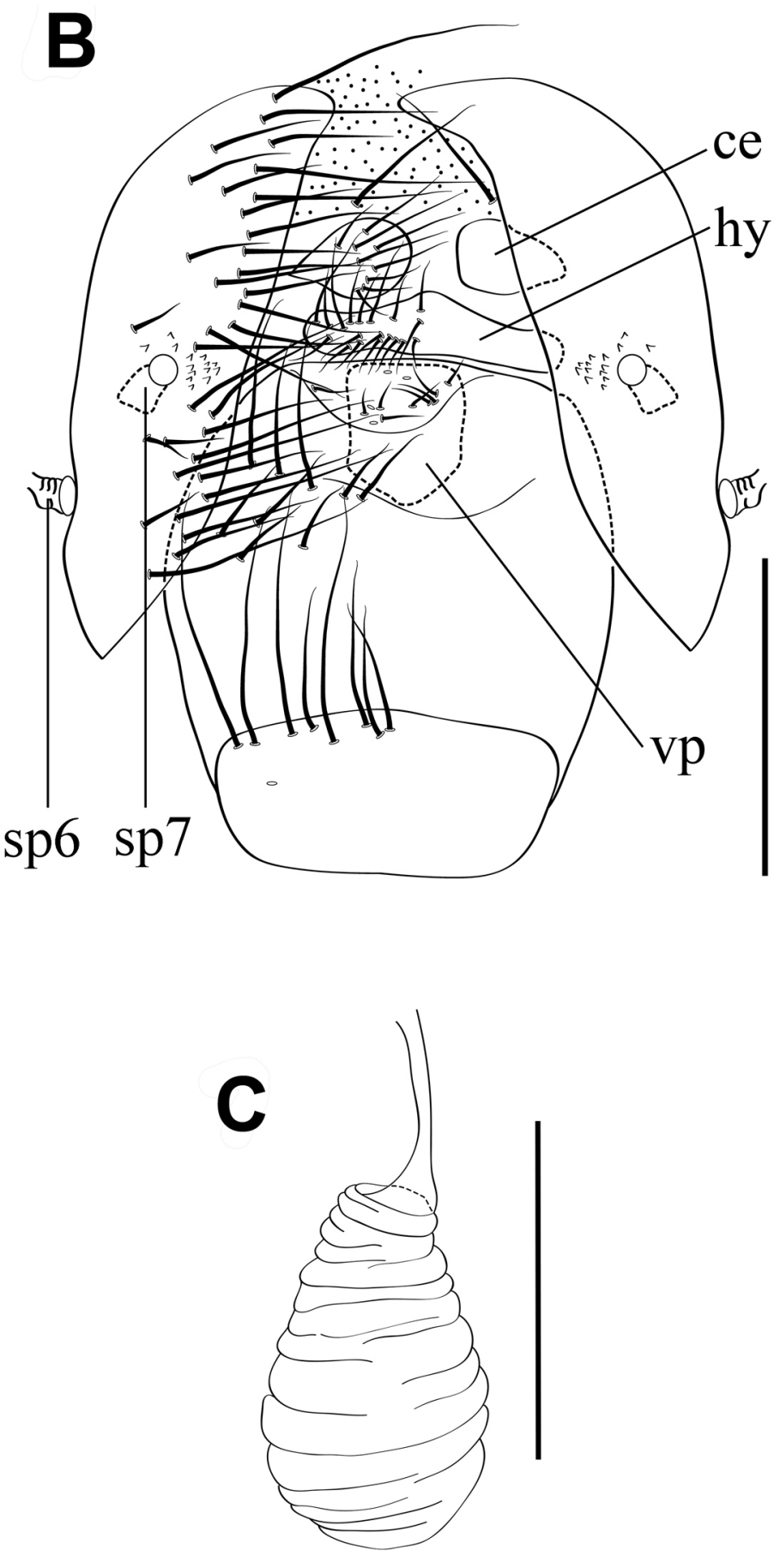

Figure 2. Oxysarcodexia digitata sp. nov. (female paratype from Itatiaia, MNRJ). (A-B) ST2-5 and terminalia, ventral view. (C) Spermathecae, lateral view. Abbreviations: ce, cercus; hy, hypoproct; sp, spiracle; ST, sternite; I, tergite; $v p$, vaginal plate. Scale bars $=0.2 \mathrm{~mm}$. 

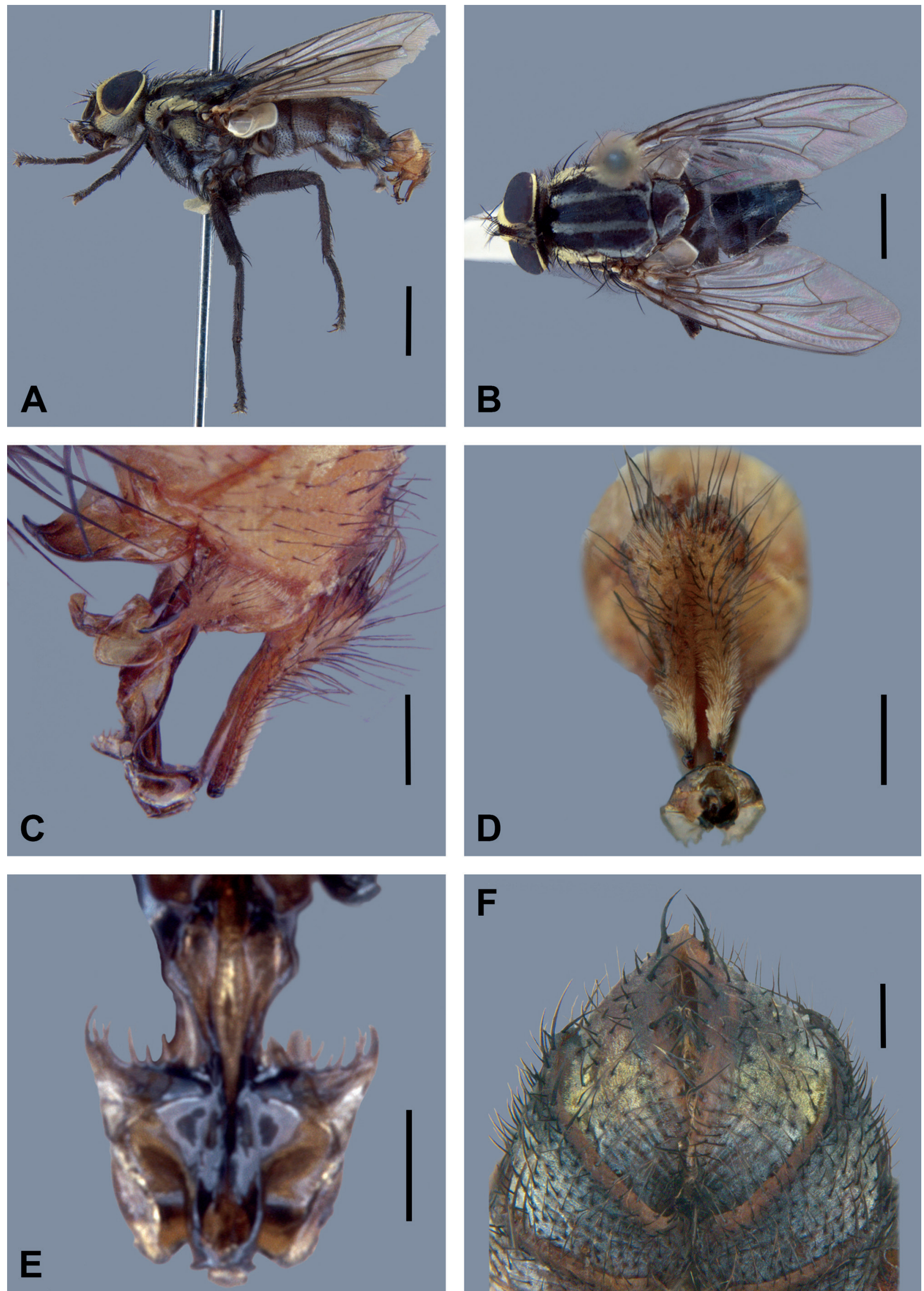

Figure 3. Oxysarcodexia digitata sp. nov. (male paratype from Boracéia, MNRJ). (A) Habitus, lateral view. (B) Habitus, dorsal view. (C) Terminalia, lateral view. (D) Terminalia, posterior view. (E) Phallus, ventral view. (F) Oxysarcodexia digitata sp. nov. (female paratype from Boracéia, MNRJ), abdomen, ventral view. Scale bars: (A-B) $4 \mathrm{~mm}$; (C-D, F) $0.8 \mathrm{~mm}$; (E) $0.4 \mathrm{~mm}$. 
Type-material: Holotype $\sigma^{\pi}(\mathrm{KU})$ [type examined through digital photographs]. "Barro Colorado I[island] / Canal Zone, Panama / 19.ii.1956 No. / C.W and M.E. Rettenmeyer [printed on white paper]" // "Xarcophaga / xon / HOLOTYPE [surrounded by a red line] / Det. H.R. Dodge 1964 [handwritten on white paper]". Condition of holotype: good condition, terminalia dissected and glued in a white cardboard, vesica partially broken at the left side. Additional examined material (MNRJ): Brazil: 5 o' and 1 o: Rio de Janeiro, Itatiaia, v.1966, breeding 769, R.P. Mello col. [lost]; 1 o': Rio de Janeiro, Itatiaia, ii.1941, P. Wichart col. [lost]; 10 : Rio de Janeiro, Itatiaia, D. Albuquerque col. [lost]; $10^{\star}:$ Santa Catarina, Nova Teutônia [Seara], $27^{\circ} 11^{\prime} S, 52^{\circ} 23^{\prime} \mathrm{W}, 18 . i .1940$, Fritz Plaumann col. [lost]; $1 \sigma^{\text {: }}$ : Rio de Janeiro, Itatiaia, P.N. Itatiaia, Rui Braga Trail, 1198 m, 22²6'09.1"S/ 44³7'31.2"W, 12-18.iii.2017, Van Someren, shrimp, Nihei et al. col. (MNRJ-ENT1-32068).

Diagnosis: Male cercus with a pointed apex slightly curved forward, in lateral view (Figs. 4A, 5C), anterior juxtal margin serrate, forming median expansions with serrate edges, and extending upward as elongated and narrow projections (Figs. 4C-D, 5C, 5E), and vesica beret-shaped, in lateral view, with a pair of basolateral squamous small lobes, in ventral view (Figs. 4C-D).

Redescription: Male $(n=9)$. Length: 7-11 mm.

Head: Parafacial, fronto-orbital plate and posterior ocular orbits dark brown with intense golden pruinosity (Figs. 5A-B); parafacial with a row of setulae close to the eye; face with golden pruinosity; facial ridge dark brown with short setulae in the inferior half; frons about $0.22-0.25 x$ head width at level of ocellar triangle; frontal vitta brownish; 8-11 well-developed frontal setae reaching the apex of pedicel, reclinate orbital seta present and more developed than the largest frontals, proclinate orbitals setae absent; ocellar setae as developed as the upper frontals; postocellar setae and paravertical setae of same size of the ocellar setae; inner vertical seta $3 \mathrm{X}$ the outer one; gena with golden pruinosity and black setae (Fig. 5A); postgena gray slightly silvery pruinose with a few black setae anteriorly and pale setae in the rest; post-cranium with two rows of black occipital setae on upper part and pale setae below; antenna dark brown (Fig. 5A), first flagellomere with silvery pruinosity and approximately $2.5 \mathrm{x}$ longer than pedicel; arista long plumose on basal 3/4; palpus dark brown (Fig. 5A). Thorax: Dark brown with golden pruinosity (Figs. 5A-B). Chaetotaxy: acrostichals $0+1$, dorsocentrals $3+3$ (well developed), intra-alars 2-3+2, supra-alars $1-2+3$, postpronotals 3, notopleurals 4; postalar wall setulose; postalar callus with 2 setae; scutellum with 3 marginal setae (well developed), a pair of discal and a pair of weak apical setae; katepisternal setae 3 , almost in a straight line; meral setae 7-10; proepisternum bare; prosternum setulose. Wing: hyaline with dark brown veins (Fig. 5B), tegula blackish, whitish-yellow basicosta, vein $\mathrm{R}_{4+5}$ with dorsal setulae on 3/4 of distance to crossvein $r-m$, vein $R_{1}$ bare, cell $r_{4+5}$ open at wing margin, costal spine not dif- ferentiated, third costal sector ventrally bare, upper and lower calypter whitish. Legs: dark brown with pulvilli yellowish-brown (Fig. 5A); fore femur with rows of dorsal, posterodorsal and posteroventral setae; fore tibia with 2 anterodorsal setae in basal third; mid femur with rows of anterior and anteroventral setae, and a row of setae and a ctenidium of flattened spines in posteroventral margin, 2 preapical posterodorsal setae; mid tibia with 1 median anterior, 1 median posterior and 1 median posterodorsal seta; hind trochanter with normal median-ventral setae; hind femur with rows of anteroventral and anterodorsal setae, 1 preapical posterior and 2 preapical posterodorsal setae; hind tibia with 1 basal third, 1 median and 1 preapical seta in anterodorsal and posterodorsal margins and 1 median anteroventral setae, sometimes with differentiated setae in series between the anterodorsals. Abdomen: Dark brown with silver stains (Fig. 5A). T4 with one pair of median marginal setae and 2-3 of lateral marginal setae; T5 with about 16 marginal setae; ST2-4 subsquadrate; ST5 yellowish brown with a median deep cleft. Terminalia: Syntergosternite $7+8$ and epandrium yellowish-brown with dorsal golden pruinosity (Fig. 5C). Cercus with pointed apex, slightly curved forward in lateral view (Figs. 4A, 5C); surstylus with apex more enlarged than base, a short apical projection in posterior margin and setae in apical third (Figs. 4A, 5C); postgonite almost straight with a setae in apical third (Figs. 4C), which can vary in size among the specimens (median to longer); pregonite similar in size to postgonite, broad, with a blackish and slightly curved apex (Fig. 4C); phallus well sclerotized, elongated and apically enlarged, basiphallus and distiphallus fused, with a ventral desclerotized band (Fig. $2 \mathrm{C}$ ); lateral triangular extension of the paraphallus poorly extended (Figs. 2C); juxta yellowish and partially membranous, anterior juxtal margin serrate, forming median expansions with serrate edges, and extending upward as elongated and narrow projections (Figs. 4C-D, 5C, 5E); vesica very pale and membranous, beret-shaped in lateral view and general rectangular format, with a pair of basolateral small lobes, in ventral view (Figs. 4C-D, 5C, 5E); median stylus with enlarged and subquadrangular base and narrow apex (Fig. 4D); lateral stylus slightly longer than median stylus with base weakly curved towards lateral (Fig. 4D).

Female $(n=1)$. Length: $8 \mathrm{~mm}$. Differs from male as follows:

Head: Frons about $0.28 \mathrm{x}$ head width at level of ocellar triangle; 2 proclinate orbital setae similar to or slightly shorter than the reclinate orbitals; outer vertical seta slightly shorter than the inner one. Thorax: Mid femur without ctenidium. Abdomen: T5 with about 14 marginal setae; posterior margin ventrally opened (Fig. 5F). Terminalia: T6 divided as two short plates largely separated from each other, with a broad area between them and the posterior margin of T5, internal margin of the plates with a row of strong marginal setae (Fig. 5F); spiracles 6 in the intersegmental membrane and spiracles 7 in tergal plate; T7 and T8 absent; ST6 with numerous marginal setae; ST7-ST8 fused, ST7 with some posterior 
A

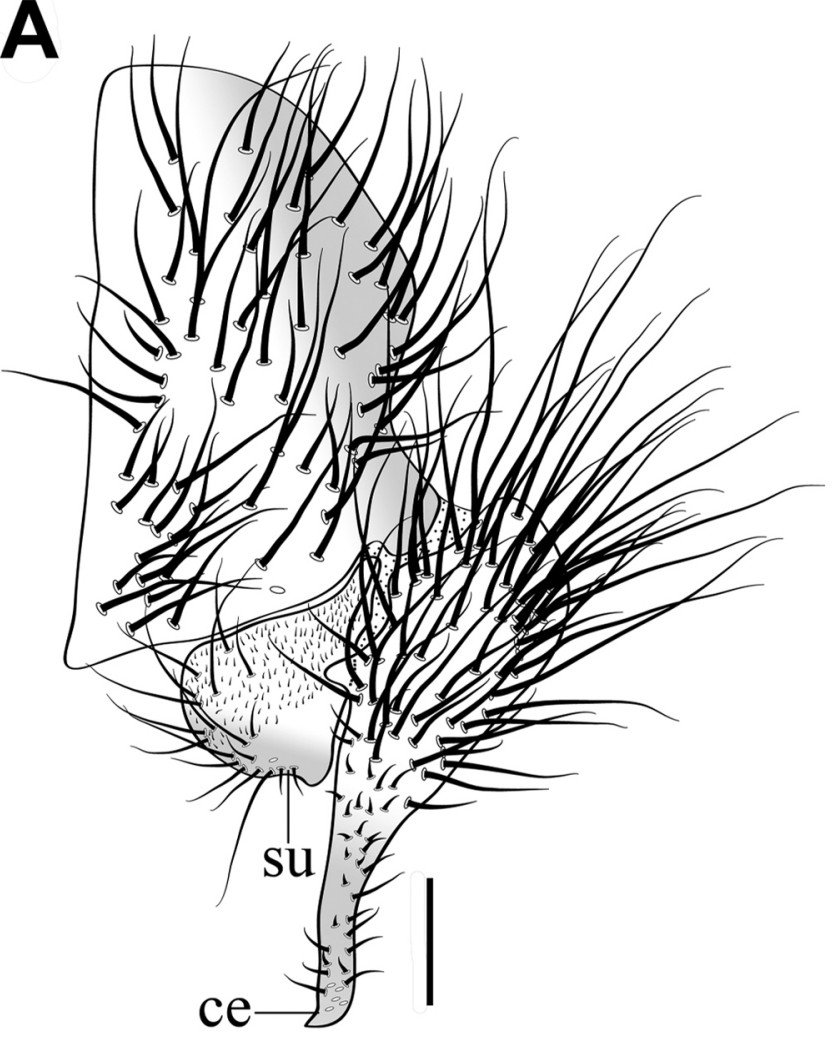

C

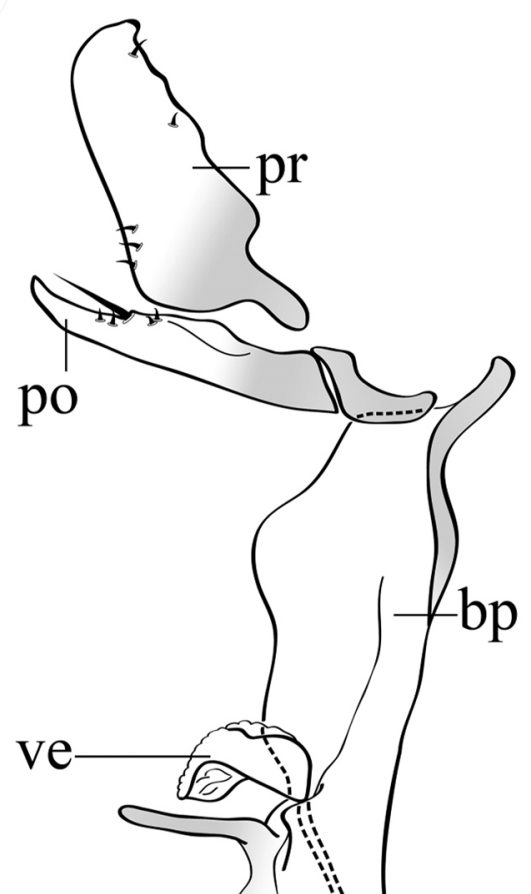

ajm

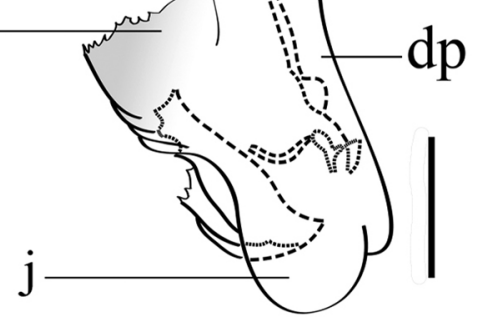

B

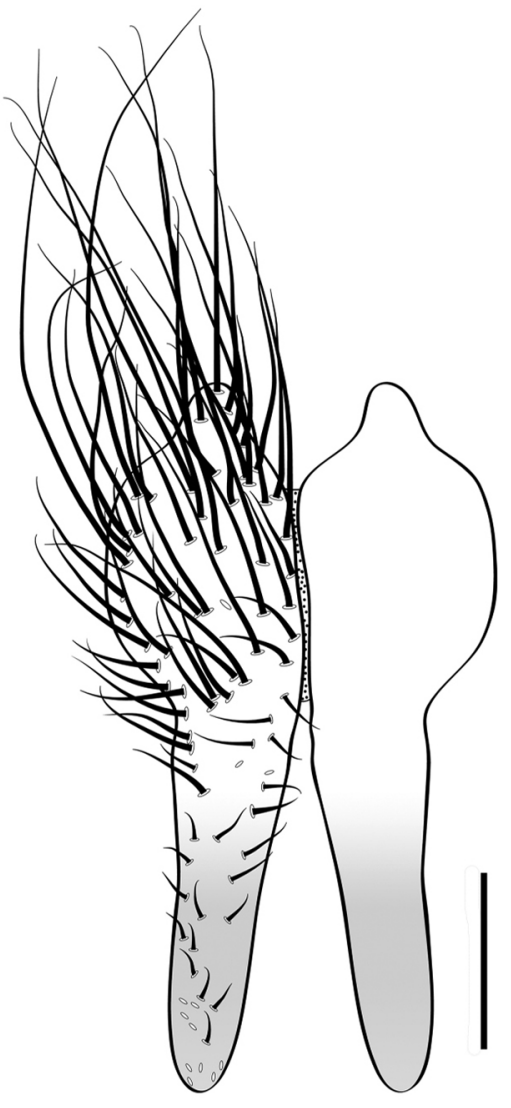

D

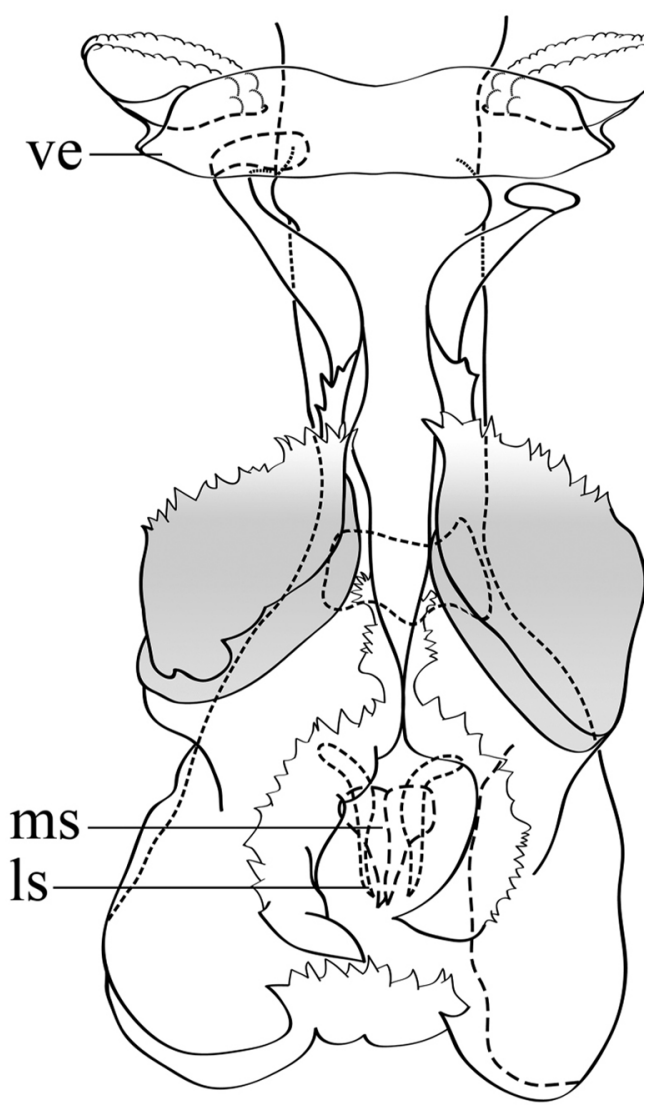

Figure 4. Oxysarcodexia xon (Dodge), (male specimen from Itatiaia, MNRJ). (A) Epandrium, cercus and surstylus, lateral view. (B) Cercus, posterior view. (C) Phallus and associated structures, lateral view. (D) Phallus ventral view. Abbreviations: ajm, anterior juxtal margin; $b p$, basiphallus; $c$, cercus; $d p$, distiphallus; $j$, juxta; Is, lateral stylus; ms, median stylus; po, postgonite; $p r$, pregonite; su, surstylus; ve, vesica. Scale bars $=0.4 \mathrm{~mm}$. 

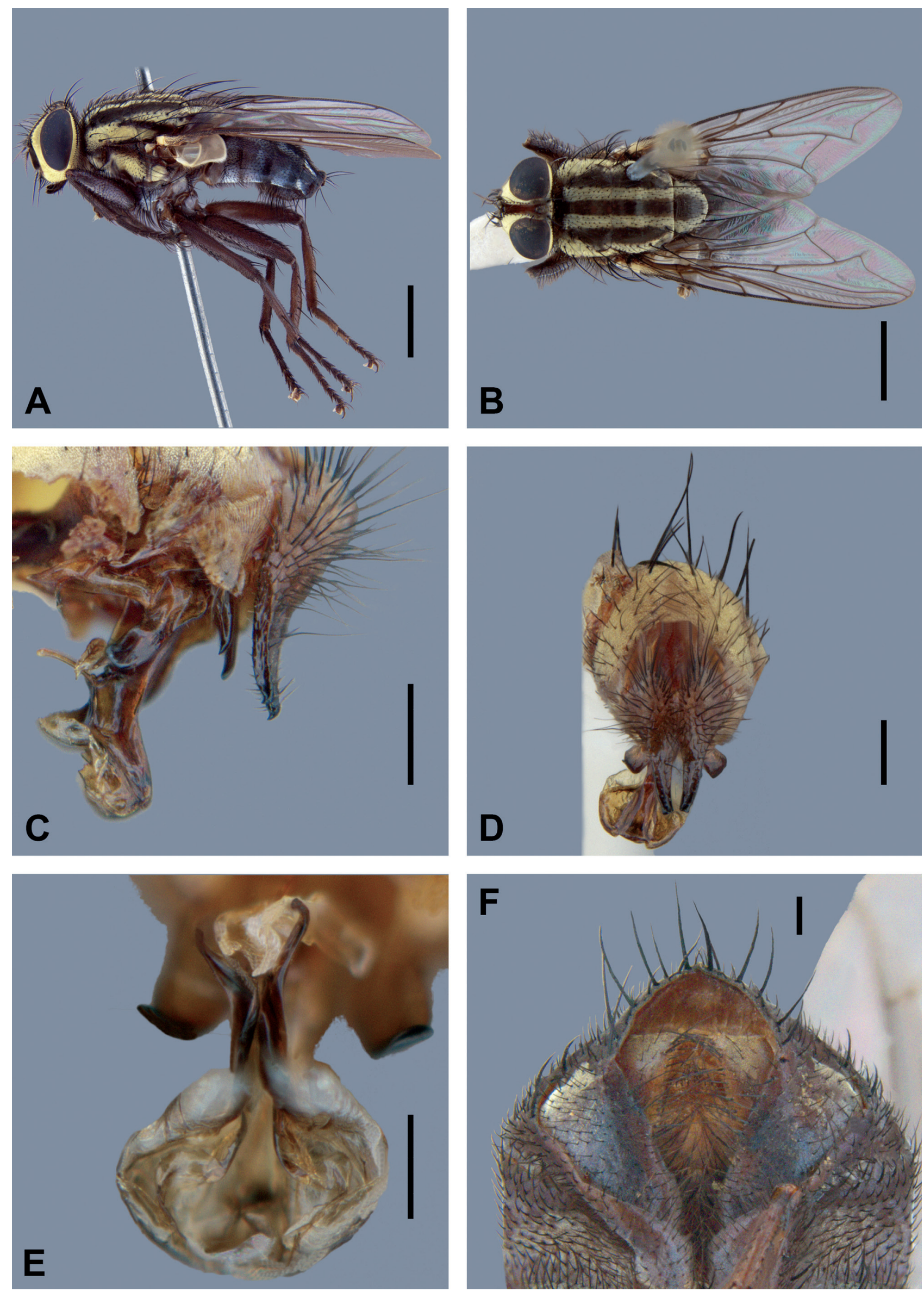

Figure 5. Oxysarcodexia xon (Dodge) (male specimen from Itatiaia, MNRJ). (A) Habitus, lateral view. (B) Habitus, dorsal view. (C) Terminalia, lateral view. (D) Terminalia, posterior view. (E) phallus, ventral view. (F) Oxysarcodexia xon (Dodge) (female specimen from Itatiaia, MNRJ), abdomen, ventral view. Scale bars: (A-B) $4 \mathrm{~mm} ;(\mathrm{C}-\mathrm{D}, \mathrm{F}) 0.8 \mathrm{~mm}$; (E) $0.4 \mathrm{~mm}$. 
setae; ST8 short with a rounded and setose apical area; epiproct membranous with one pair of setae; hypoproct broad with long setae; cercus large and rounded.

Distribution: Brazil (Rio de Janeiro, Santa Catarina*); Panama.

Remarks: Oxysarcodexia xon closely resembles 0 . digitata sp. nov., O. nitida Soares \& Mello-Patiu and O. notata Soares \& Mello-Patiu, since both are more similar in shape of the surstylus and vesica, but differs from other species by the cercus end pointed and end pointed and slightly curved forward in lateral view (Figs. 4A, 5C), pregonite short and broad (Fig. 4C), anterior juxtal margin serrate, forming median expansions with serrate edges, and extending upward as elongated and narrow projections (Figs. 4C-D, 5C, 5E), and vesica small with squamous lobes (Figs. 4C-D, 5E).

\section{DISCUSSION}

Early authors considered Oxysarcodexia species with apical phallic enlargement under the distinct genus Xarcophaga (Dodge, 1968, Lopes, 1982), but current authors have dealt with these species under Oxysarcodexia, following the synonymic proposal of Lopes (1975a) and Pape (1996), although species with phallic enlargement have been referred as "Xarcophaga group" or "xon species-group" (Soares \& Mello-Patiu, 2010; Souza \& Paseto, 2015; Souza \& Buenaventura, 2016; Dufek \& Mulieri, 2017). However, until now there is no formal proposition between species-groups or subgenera in Oxysarcodexia. Indeed, Oxysarcodexia has been included in some phylogenetic analysis based on morphological or molecular data (Giroux et al., 2010; Kutty et al., 2010; Stamper et al., 2013; Piwczyński et al., 2014; Buenaventura \& Pape $2015,2017)$, but most of them only included species of Oxysarcodexia sensu strictu and no representatives of Xarcophaga, Hybopygia, or Apelophyla in order to test the position of these taxa in this huge genus or monophyletic species-groups, except for the phylogeny by Buenaventura \& Pape (2017), who also included one representative of Hybopygia, which was deeply nested in the monophylum of genus Oxysarcodexia, but did not allow a monophyly test of the "xon species-group".

\section{ACKNOWLEDGEMENTS}

We are grateful to Dr. Silvio Nihei (USP) for donating material that allowed us to continue this work, as the previously studied specimens were lost in the fire of MNRJ, to Dr. Michael Engel (University of Kansas, Biodiversity Institute, Lawrence, KU), who kindly provided photos of the Oxysarcodexia xon holotype, to Daniel Whitmore for helpful comments on a later version of the manuscript, and to anonymous reviewers for corrections and suggestions which improved this manuscript. To FAPERJ (Fundação Carlos Chagas Filho de Amparo à Pesquisa no
Estado do Rio de Janeiro (Proc. E-26/200.078/2019) for financial support. CAMP is supported by CNPq Research fellowship (grant 308951/2018-2), MAM and JRS are supported by CAPES PhD scholarship.

\section{REFERENCES}

Alves, A.C.F.; Dos Santos, E. \& Creão-Duarte, A.J. 2014. Diptera (Insecta) de importância forense da região Neotropical. Entomotropica, 29: 77-94.

Barbosa, R.R.; Mello-Patiu, C.A.; Mello, R.P.D. \& Queiroz, M.M.D.C. 2009. New records of calyptrate dipterans (Fanniidae, Muscidae and Sarcophagidae) associated with the decomposition of domestic pigs in Brazil. Memórias do Instituto Oswaldo Cruz, 104(6): 923-926.

Barbosa, T.M.; Carmo, R.F.R.; Silva, L.P.; Sales, R.G. \& Vasconcelos, S.D. 2017. Diversity of sarcosaprophagous Calyptratae (Diptera) on sandy beaches exposed to increasing levels of urbanization in Brazil. Environmental Entomology, 46(3): 460-469.

Barros, R.M.; Mello-Patiu, C.A.\& Pujol-Luz, J.R. 2008. Sarcophagidae (Insecta, Diptera) associados à decomposição de carcaças de Sus scrofa Linnaeus (Suidae) em área de Cerrado do Distrito Federal, Brasil. Revista Brasileira de Entomologia, 52(4): 606-609.

Battán Horenstein, M.; Linhares, A.X.; Rosso de Ferradas, B. \& Garcia, D. 2010. Decomposition and dipteran succession in pig carrion in central Argentina: ecological aspects and their importance in forensic science. Medical and Veterinary Entomology, 24: 16-25.

Buenaventura, E. \& Pape, T. 2015. Phylogeny of the Peckia-genus group: evolution of male genitalia in the major necrophagous guild of Neotropical flesh flies (Diptera: Sarcophagidae). Organisms Diversity \& Evolution, 15: 301-331.

Buenaventura, E. \& Pape, T. 2017. Phylogeny, evolution and male terminalia functionality of Sarcophaginae (Diptera: Sarcophagidae), Zoological Journal of the Linnean Society, 183(4): 808-906.

Carvalho, C.J.B.; Rafael, J.A.; Couri, M.S. \& Silva, V.C. 2012. Diptera. In: Rafael, J.A.; Melo, G.A.R.; Carvalho, C.J.B.; Casari, S. \& Constantino, C. (Eds.). Insetos do Brasil: diversidade e taxonomia. Ribeirão Preto, São Paulo, Holos Editora. p. 701-743.

Carvalho, C.J.B.D. \& Mello-Patiu, C.A. 2008. Key to the adults of the most common forensic species of Diptera in South America. Revista Brasileira de Entomologia, 52(3): 390-406.

Carvalho, L.M.L.; Thyssen, J.; Linhares, A.X. \& Palhares, F.A.B. 2000. A checklist of arthropods associated with pig carrion and human corpses in Southeastern Brazil. Memórias do Instituto Oswaldo Cruz, 95(1): 135-138.

Carvalho-Filho, F.S.; Sousa, J.R.P \& Esposito, M.C. 2017. A new species and new records of Oxysarcodexia Townsend (Diptera: Sarcophagidae) from Brazil. Revista Brasileira de Entomologia, 61(4): 349-353.

Cumming, J.M. \& Wood, D.M. 2017. 3. Adult morphology and terminology. In: Kirk-Spriggs, A.H. \& Sinclair, B.J. (Eds.). Manual of Afrotropical Diptera. Volume 1. Introductory chapters and keys to Diptera families. Suricata 4. Pretoria, South African National Biodiversity Institute.,p. 89-133.

De Faria, L.S.; Paseto, M.L.; Couri, M.S.; Mello-Patiu, C.A. \& Mendes, J. 2017. Insects Associated with Pig Carrion in Two Environments of the Brazilian Savanna. Neotropical Entomology, 46: 1-18.

Dodge, H.R. 1966. Some new or little-known Neotropical Sarcophagidae (Diptera), with a review of the genus Oxysarcodexia. Annals of the Entomological Society of America, 59(4): 674-701.

Dodge, H.R. 1968. The Sarcophagidae of Barro Colorado Island, Panama (Diptera). Annals of the Entomological Society of America, 61: 421-450.

Duarte, L.F.D. 2019. 0 Museu Nacional: ciência e educação numa história institucional brasileira. Horizontes Antropológicos, 25(53): 359-384. 
Dufek, M.I. \& Mulieri, P.R. 2017. Two new species of Oxysarcodexia Townsend (Diptera: Sarcophagidae) from the Chaco Forest ecoregion of South America. Journal of Medical Entomology, 54(4): 917-924.

Giroux, M.; Pape, T.\&Wheeler, T.A. 2010. Towards a phylogeny of the flesh flies (Diptera: Sarcophagidae): morphology and phylogenetic implications of the acrophallus in the subfamily Sarcophaginae. Zoological Journal of the Linnean Society, 158(4): 740-778.

Kutty, S.N.; Pape, T.; Wiegmann, B.M. \& Meier, R. 2010. Molecular phylogeny of the Calyptratae (Diptera: Cyclorrhapha) with an emphasis on the superfamily Oestroidea and the position of Mystacinobiidae and McAlpine's fly. Systematic Entomology, 35(4): 614-635.

Lindgren, N.K.; Sisson, M.S.; Archambeault, A.D.; Rahlwes, B.C.; Willelett, J.R. \& Bucheli, S.R. 2015. Four forensic entomology case studies: records and behavioral observations on seldom reported cadaver fauna with notes on relevant previous occurrences and ecology. Journal of Medical Entomology, 52(2): 143-150.

Lopes, H.S. 1935. Notas sobre Sarcophagidae com descrição de três espécies novas do Brasil (Diptera). Revista de Entomologia, Rio de Janeiro, 5: 315-322.

Lopes, H.S. 1946. Contribuição ao conhecimento das espécies do gênero Oxysarcodexia Townsend, 1917 (Diptera, Sarcophagidae). Boletim da Escola Nacional de Veterinária, 1: 62-134.

Lopes, H.S. 1975a. New or little known Oxysarcodexia (Diptera, Sarcophagidae). Revista Brasileira de Biologia, 35(3): 461-483.

Lopes, H.S. 1975b. Some new Sarcophagidae from Peru (Diptera). Revista Brasileira de Biologia, 35(4): 573-580.

Lopes, H.S. 1982. The importance of the mandible and clypeal arch of the first instar larvae in the classification of the Sarcophagidae (Diptera). Revista Brasileira de Entomologia, 26(3-4): 293-326.

Lopes, H.S. \& Tibana, R. 1987. On Oxysarcodexia (Diptera, Sarcophagidae), with descriptions of five new species, key, list and geographic distribution of the species. Revista Brasileira de Biologia, 47(3): 329-347.

Martínez, E.; Duque, P. \& Wolff, M. 2007. Succession pattern of carrion feeding insects in Paramo, Colombia. Forensic Science International, 166(2-3): 182-189.

Mello-Patiu, C.A. \& Pape, T. 2000. Definitions of Dexosarcophaga Townsend, 1917 and Sarcofartiopsis Hall, 1933, including two new species and redescriptions of Sarcofartiopsis cuneata (Townsend, 1935) (Diptera, Sarcophagidae). Boletín de Entomología Venezolana, 15: 181-194.

Mello-Patiu, C.A. \& Santos, J.M. 2001. Nephochaetopteryx Townsend 1934: descriptions and comparative morphological notes of the female terminalia (Diptera, Sarcophagidae). Studia Dipterologica, 8: 303-315.

Mello-Patiu, C.A.; Soares, W.F. \& Silva, K.P. 2009. Espécies de Sarcophagidae (Insecta: Diptera) registradas no estado do Rio de Janeiro. Arquivos do Museu Nacional do Rio de Janeiro, 67: 173-188.

Mendes, J. \& Linhares, A.X. 2002. Cattle dung breeding Diptera in pastures in southeastern Brazil: Diversity, abundance and seasonality. Memórias do Instituto Oswaldo Cruz, 97: 37-41.
Oliveira, T.C. \& Vasconcelos, S.D. 2010. Insects (Diptera) associated with cadavers at the Institute of Legal Medicine in Pernambuco, Brazil: Implications for forensic entomology. Forensic Science International, 198: 97-102.

Oliveira-Costa, J.; Lamego, C.M.D.; Couri, M.S. \& Mello-Patiu, C.A. 2014. Differential Diptera succession patterns onto partially burned and unburned pig carrion in southeastern Brazil. Brazilian Journal of Biology, 74(4): 870-876.

Oliveira-Costa, J.; Mello-Patiu, C.A. \& Lopes, S.M. 2001. Dípteros muscoides associados com cadáveres humanos na cena da morte no estado do Rio de Janeiro, Brasil. Boletim do Museu Nacional, 464: 1-6.

Pape, T. 1996. Catalogue of the Sarcophagidae of the world (Insecta: Diptera). Memoirs on Entomology International, 8: 1-558.

Pape, T. \& Dahlem, G.A. 2010. Sarcophagidae. In: Brown, B.V.; Borkent, A.; Cumming, J.M.; Wood, D.M.; Woodley, N.E. \& Zumbado, M. (Eds.). A manual of Central American Diptera. Ottawa, NRC Research Press, v.2, $728 \mathrm{p}$.

Piwczyński, M.; Szpila, K.; Grzywacz, A. \& Pape, T. 2014. A large-scale molecular phylogeny of flesh flies (Diptera: Sarcophagidae). Systematic Entomology, 39(4): 783-799.

Silva, K.P. \& Mello-Patiu, C.A. 2008. Morfologia comparada da terminália masculina de quatro espécies de Oxysarcodexia Townsend, 1917 (Diptera, Sarcophagidae). Arquivos do Museu Nacional do Rio de Janeiro, 66: 363-372.

Soares, W.F. \& Mello-Patiu, C.A. 2010. Two new Neotropical species of the genus Oxysarcodexia Townsend (Diptera, Sarcophagidae). Revista Brasileira de Entomologia, 54: 72-75.

Sousa, J.R.P.; Carvalho-Filho, F.S. \& Esposito, M.C. 2015. Distribution and abundance of necrophagous flies (Diptera: Calliphoridae and Sarcophagidae) in Maranhão, Northeastern Brazil. Journal of Insect Science, 15: 1-10.

Souza, C.M. \& Buenaventura, E. 2016. Three new species of Oxysarcodexia Townsend (Diptera: Sarcophagidae) from the Colombian Andes. Zootaxa, 4084: 115-124.

Souza, C.M. \& Paseto, M.L. 2015. Description of a Neotropical New Species of Oxysarcodexia Townsend, 1917 (Diptera: Sarcophagidae). EntomoBrasilis, $8(3): 222-225$

Stamper, T.; Dahlem, G.A.; Cookman, C. \& DeBry, R.W. 2013. Phylogenetic relationships of flesh flies in the subfamily Sarcophaginae based on three mtDNA fragments (Diptera: Sarcophagidae). Systematic Entomology, 38: 35-44.

Walker, F. 1836. Diptera, pp. 331-359. In: Curtis, J.; Haliday, A.H. \& Walker, F. (Eds.). Descriptions, \&c. of insects collected by Captain P.P. King, R.N., F.R.S., in the survey of the Straights of Magellan. Transactions of Linnean Society, London, 17(3): 315-359.

Whitmore, D., Pape, T. \& Cerretti, P. 2013. Phylogeny of Heteronychia: the largest lineage of Sarcophaga (Diptera: Sarcophagidae). Zoological Journal of the Linnean Society, 169(3): 604-639. 